\title{
Development and Validation of Reverse-Phase High-Performance Liquid Chromatographic Method for Determination of Resveratrol in Human and Rat Plasma for Preclinical and Clinical Studies
}

\author{
Satveer Jagwani ${ }^{1,2}$, Sunil Jalalpure ${ }^{1,2 *}$, Dinesh Dhamecha², Gan Siew Hua ${ }^{3}$, Kiran Jadhav1 \\ ${ }^{1}$ KLE College of Pharmacy, KLE Academy of Higher Education and Research, Nehru Nagar, Belagavi, Karnataka, INDIA. \\ ${ }^{2}$ Dr. Prabhakar Kore Basic Science Research Center, KLE Academy of Higher Education and Research, Nehru Nagar, Belagavi, \\ Karnataka, INDIA. \\ ${ }^{3}$ School of Pharmacy, Monash University-Malaysia, Jalan Lagoon Selatan, Bandar Sunway, Selangor, MALAYSIA.
}

\begin{abstract}
Aim: The aim of the study was to develop and validate a simple and precise reverse-phase High Performance Liquid Chromatography (RP-HPLC) method for quantitative analysis of trans-resveratrol in human and rat plasma. Methods: HPLC method was developed by using Phenomenex Luna $C_{18}$ column $(150 \times 4.6 \mathrm{~mm}, 5 \mu \mathrm{m})$ and the optimized mobile phase comprised of acetonitrile/water in isocratic mode $(30: 70, \mathrm{v} / \mathrm{v})$ with the flow rate of $1.0 \mathrm{~mL} / \mathrm{min}$. Trans-resveratrol was detected at a UV wavelength of $306 \mathrm{~nm}$. Developed method was validated as per International Conference on Harmonization (ICH) M10 guidelines. Results: The proposed method was found simple, precise and linear with regression coefficient of 0.999 which could analyse the samples in nanograms levels with mean percent recovery in the acceptable range of $94.44-97.44 \%$. The method was precise at the intra-day and inter-day levels as reflected by the relative standard deviation values (less than $3.36 \%$ ). Trans resveratrol was found to be stable in plasma under different storage conditions. Conclusion: The present investigation demonstrated that the developed method was succesfully applied to accurately determine transresveratrol in human and rat plasma and therefore can be applicable for pre-clinical and clinical studies.
\end{abstract}

Key words: RP-HPLC, Trans resveratrol, Human plasma, Rat plasma, Storage stability studies.

\section{INTRODUCTION}

Recently, various food constituents, mainly polyphenols have gained wide attention either as a potential therapeutic or as prophylactic agent in the management of several diseases. ${ }^{1}$ Resveratrol (3,5,4'- trihydroxystilbene), a well-known naturally occurring lipophilic polyphenol is first isolated from white hellebore and also present in wide range of other plant products including cranberry, grapevine, blueberry, bilberry and peanut., ${ }^{2,3}$ Resveratrol has two isomers cis and trans from which, the transresveratrol is the therapeutically active form
(Figure 1) responsible for health-promoting pharmacological effects like antioxidant, anti-aging, cardioprotective, neuroprotective, anti-inflammatory and anticancer properties. ${ }^{4}$ Although trans-resveratrol has shown promising results in several diseases but its unfavorable pharmacokinetic properties such as low bioavailability, extensive metabolism and short half-life limits its use in clinical applications. ${ }^{5}$ Currently, trans-resveratrol has been widely incorporated as a nutritional supplement in the day-today life and to consume it as a drug, it is important
Submission Date: 16-05-2019; Revision Date: 22-08-2019; Accepted Date: 02-12-2019

DOI: 10.5530/ijper.54.1.22 Correspondence: Dr. Sunil Jalalpure, ${ }^{1}$ Professor, KLE College of Pharmacy, KLE Academy of Higher Education and Research, Nehru Nagar, Belagavi, Karnataka, INDIA ${ }^{2}$ Dr. Prabhakar Kore Basic Science Research Center, KLE Academy of Higher Education and Research, Nehru Nagar, Belagavi-590010 Karnataka, INDIA.

Phone: +91 9448964057

E-mail: jalalpuresunil@ rediffmail.com

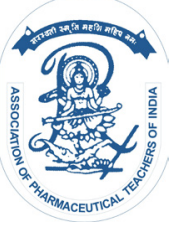

www.ijper.org 


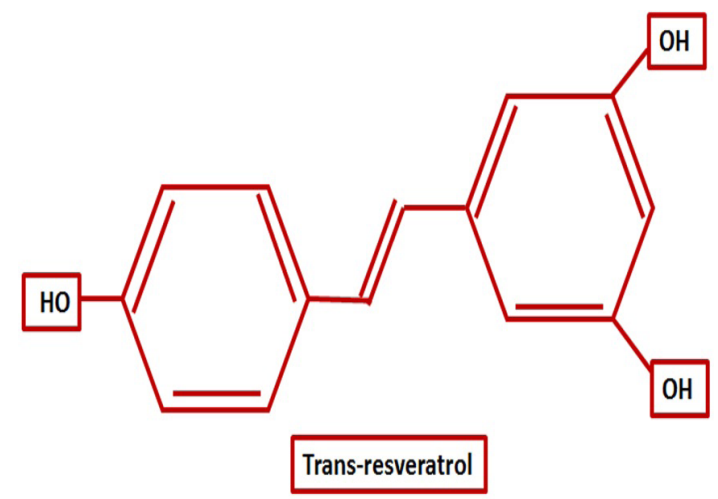

Figure 1: Structure of trans-resveratrol.

to develop an appropriate drug delivery systems which can overcome the problems related to its pharmacokinetic. Several HPLC methods are reported in the literature to quantify trans resveratrol in human and rat plasma. ${ }^{2,5-9}$ However, the reported RP-HPLC methods present several limitations such as long run times, high flow rates, complicated gradient elutions and buffer solutions in mobile phase. The necessity for development of a reliable analytical method for drug assay in biological fluids is a prerequisite for pharmacokinetic studies in animal models and human subjects.

With this background, the aim of the study was to develop a simple, rapid and selective RP-HPLC method in accordance with U.S. Food and Drug Administration and ICH guideline ${ }^{10,11}$ to quantify trans-resveratrol in human and rat plasma.

\section{MATERIALS AND METHODS}

\section{Materials}

Trans-resveratrol (99\% pure) and carbamazepine were obtained as free samples from Ms. Sami Labs Ltd., Bangalore, India and Alkem Laboratories Ltd., Mumbai, India, respectively. HPLC-grade acetonitrile (ACN) and methanol were procured from Merck, Mumbai, India. Whole human blood was obtained from K.L.E.S. Dr. Prabhakar Kore Hospital and Medical Research Centre blood bank, (Nehru Nagar, Belagavi-590010, Karnataka, India) and was processed to obtained blank plasma. Deionized water used in the tests was prepared by filtering water through Millipore Direct- $\mathrm{Q}^{\circledR}-3$ purification system $(18.2 \mathrm{M} \Omega / \mathrm{cm})$ Millipore (Molsheim, France).

\section{Instrument}

The HPLC system (LC-20AD prominence system, Shimadzu, Kyoto, Japan) consisted of an LC-20AD pump, SIL-20 AC HT autosampler, SPD-M20A diode array detector and CBM-20A communication bus module, which was functioned by using computer based Shi- madzu LC solution (version 1.25) software program to analyse the chromatograms. A reverse phase Luna $\mathrm{C}_{18}$ column (150 x $4.6 \mathrm{~mm}$ i.d., $5 \mu \mathrm{m}$ particle size, Phenomenex, USA) equipped with a guard column (ODS; $4 \times 3.0 \mathrm{~mm}$ ID, Phenomenex, CA, USA) with a similar particle size was used for separation.

\section{Chromatographic conditions}

System was operated with isocratic elution of ACN: Deionized water $(30: 70 \mathrm{v} / \mathrm{v})$ as mobile phase at a flow rate of $1.0 \mathrm{~mL} / \mathrm{min}$ under a controlled temperature $\left(30^{\circ} \mathrm{C}\right)$ condition. Solvents were prepared by degassing in bath sonicator for 10 min followed by filteration through $0.45 \mu \mathrm{m}$ membrane Millex HV polyvinylidene fluoride membrane filters (Millipore, Bedford, USA) by using vaccum pump. Drug samples $(20 \mu \mathrm{l})$ was injected in HPLC system and detected at $306 \mathrm{~nm}$.

\section{Method validation}

Developed method was validated for its selectivity, linearity, system suitability, Limit of Detection (LOD), Limit of Quantitation (LOQ), precision, accuracy and stability.

\section{Human and rat plasma samples preparations}

Animal experiments was approved by the Institutional Animal Ethical Committee, KLE College of Pharmacy, Belagavi, India. Human and rat blood samples were centrifuged at $3000 \mathrm{rpm}$ for $10 \mathrm{~min}$ at $4^{\circ} \mathrm{C}$ for plasma separation. ${ }^{12}$ The stock solution of the drug was spiked in rat and human plasma to get final concentrations of 2, 4, 6, 8, 10, $12 \mu \mathrm{g} \mathrm{mL}^{-1}$ (trans-resveratrol). Protein precipitation was performed by treating the spiked plasma samples $(150 \mu \mathrm{L})$ with acetonitrile $(100 \mu \mathrm{L})$ followed by centrifugation at $10000 \mathrm{rpm}$ for $10 \mathrm{~min}$ at $4^{\circ} \mathrm{C}$. Finally, the supernatant was carefully seperated and loaded into the HPLC autosampler for analysis. ${ }^{13}$

\section{Stability experiments}

Trans-resveratrol stability was determined in the human and rat plasma at different storage conditions as follows: stability for up to $6 \mathrm{~h}$ at $25^{\circ} \mathrm{C}$, freezer stability up to 7 days $\left(\right.$ at $\left.-20^{\circ} \mathrm{C}\right)$ and freeze-thaw stability $\left(\right.$ at $\left.-20^{\circ} \mathrm{C}\right)$. In freeze-thaw stability, cycles were conducted for thrice and the samples were restored to the same condition after withdrawal of aliquots for analysis. The peak areas of the trans-resveratrol obtained at $0 \mathrm{~h}$ were used as the reference to determine the relative stability at various storage conditions. All the experiment were performed in triplicates and the samples were considered as stable if the assay values were within the acceptable limit of accuracy (i.e. $\pm 15 \%$ standard deviation). ${ }^{14}$ 


\section{RESULTS AND DISCUSSION}

\section{Method development}

Preceding to the validation step, the proposed method was developed in order to provide a simple and optimized procedure, with reduced time and cost of analysis. Therefore, different chromatographic parameters were considered, namely peak number of theoretical plates $(\mathrm{N})$, symmetry (as described by the tailing factor, T), resolution, HETP and retention factor $\left(\mathrm{k}^{\prime}\right)$. Initially, the developed RP-HPLC method was optimized by altering the mobile phase composition to obtain symmetrical peak. Varying ratios of solvents mainly consisting of ACN and deionized water with or without methanol was used to optimise the resolution of the peak. Solvent composition consisting of methanol and water in the ratio of 50:50 v/v might yield clear trans-resveratrol peak but had a undesirable impact on the theoretical plate number whereas, solvent composition consisting of ACN and deionized water 50:50 v/v yielded well resolved peak with minor tailing. For the separation of trans-resveratrol, several proportions of $\mathrm{ACN}$ and water were tested ranging from 90:10 to 40:60 and analysed to get sharp peak with negligible tailing and shorter retention time. Apart from the mobile phase selection, column temperature is one of the key parameter that demonstrate the significant effect on retention time and peak shape of trans-resveratrol. Experiments with colum temperature in the ranging from $25^{\circ} \mathrm{C}$ to $45^{\circ} \mathrm{C}$ revealed that $30^{\circ} \mathrm{C}$ demonstrated clear peak shape and shorter retention time when compared to others.

The developed HPLC system with Luna $\mathrm{C}_{18}$ column $(150 \times 4.6 \mathrm{~mm}$ i.d., $5 \mu \mathrm{m})$ was validated by using a solvent mixture of $\mathrm{ACN}$ and deionized water (30:70) with isocratic elution at $1.0 \mathrm{~mL} / \mathrm{min}$. The injection volume was set up at $20 \mu \mathrm{L}$ with column temperature of $30^{\circ} \mathrm{C}$. Under these chromatographic conditions, trans-resveratrol was detected at wavelength of $306 \mathrm{~nm}$ with retention time of $6.1 \mathrm{~min}$ (Figure 2).

\section{Method validation}

\section{System suitability and selectivity tests}

System suitability test is an vital part of the HPLC method development which defines the feasibility and acceptability of the proposed method for the estimation of trans-resveratrol in the plasma. The results of the tested parameters along with their acceptance criteria are summarized in Table 1. All the parameters such as retention factor $(>2)$, tailing factor $(<2)$, resolution $(>2)$ and theoretical plate number $(>2000)$ were found to be within the acceptable limits demonstrating desirable resolution, peak symmetry, column efficiency and

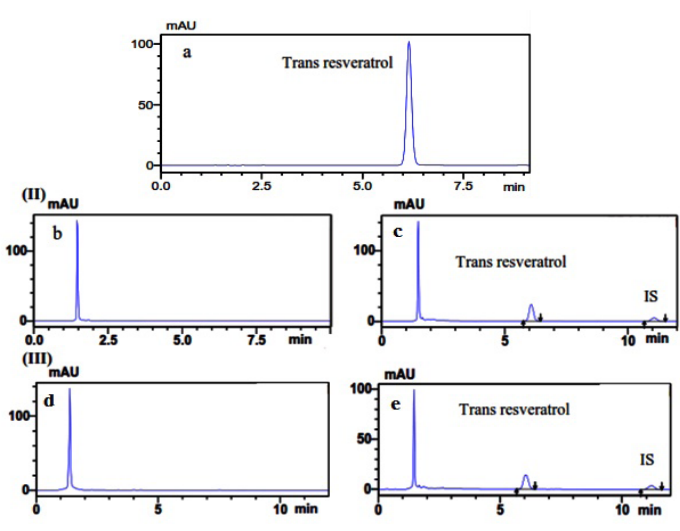

Figure 2: Representative chromatogram obtained from a) pure trans resveratrol $\left(6 \mu \mathrm{g} \mathrm{mL}^{-1}\right)$ b) blank human plasma c) human plasma spiked with pure trans resveratrol at $6 \mu \mathrm{g} \mathrm{mL}^{-1}$ and internal standard (IS) carbamezapine at $20 \mu \mathrm{g} \mathrm{mL}^{-1} \mathrm{~d}$ ) blank rat plasma e) rat plasma spiked with pure trans resveratrol at $6 \mu \mathrm{g}$ $\mathrm{mL}^{-1}$ and internal standard (IS) carbamezapine at $20 \mu \mathrm{g} \mathrm{mL}^{-1}$. Retention time of pure resveratrol and IS are 6.1 and $11.2 \mathrm{~min}$, respectively.

\begin{tabular}{|c|c|c|c|}
\hline \multicolumn{4}{|c|}{ Table 1: System suitability parameters. } \\
\hline Parameter & $\begin{array}{c}\text { Human } \\
\text { plasma }\end{array}$ & $\begin{array}{c}\text { Rat } \\
\text { plasma }\end{array}$ & $\begin{array}{c}\text { Acceptance } \\
\text { criteria }\end{array}$ \\
\hline $\begin{array}{c}\text { Retention time }\left(\mathrm{R}_{\mathrm{t}^{\prime}}\right. \\
\text { min) }\end{array}$ & $\begin{array}{c}6.055 \pm \\
0.004\end{array}$ & $\begin{array}{c}6.051 \pm \\
0.003\end{array}$ & - \\
\hline Peak area & $\begin{array}{c}171352.3 \pm \\
1173.212\end{array}$ & $\begin{array}{c}172503.7 \pm \\
1329.123\end{array}$ & - \\
\hline Tailing factor $(\mathrm{T})$ & 1.11 & 1.09 & $\leq 2.0$ \\
\hline $\begin{array}{c}\text { Theoretical plates } \\
(\mathrm{N})\end{array}$ & 8504.00 & 4454.00 & $>2000$ \\
\hline Resolution & 26.21 & 10.92 & $>2$ \\
\hline & & 0.03 & $\begin{array}{c}\text { Smaller } \\
\text { the value } \\
\text { the higher } \\
\text { column } \\
\text { efficiency }\end{array}$ \\
\hline HETP & 0.01 & 3.10 & $>2$ \\
\hline
\end{tabular}

Values are express as mean \pm standard deviation (SD); $(n=6)$

excellent chromatographic conditions which was used for further validation and sample analysis. Selectivity is described as the ability of a method to separate the analyte from all possibly interfering substance. The selectivity of the method was examined by analyzing blank human and rat plasma detection and spiking with pure compound. Figure 2 shows that there were no interference of plasma in resveratrol elution.

\section{Linearity and range}

The linearity of a method is defined as the relationship between the peak area and its corresponding concentrations in the sample solutions. The developed method was found to be linear (Figure 3) over the range of $2-$ 
$12 \mu \mathrm{g} \mathrm{mL}{ }^{-1}$ with correlation coefficient; $r^{2}=0.999$ (Table 2) indicating acceptable linearity over the proposed concentration range.

\section{LOD and LOQ}

The LOD and LOQ were determined by diluting the known concentration of the drug until a signal to noise ratio of nearly 3:1 and 10:1 were obtained (Table 2). The lowest concentration of trans-resveratrol detected in human and rat plasma was 0.030 and $0.032 \mu \mathrm{g} \mathrm{mL}^{-1}$ respectively. Whereas, the limit of quantitation in the human plasma and rat plasma was found to be 0.090 and $0.099 \mu \mathrm{g} \mathrm{mL}{ }^{-1}$ respectively.

\section{Precision}

The precision of an analytical method indicates the closeness of agreement between the series of measurements obtained from multiple samplings of the identical sample under the similar analytical conditions. Both inter-day (at three consecutive days) and intra-day (repeatability) assays were performed at three different concentrations (in triplicates) and results are shown in Table 3. The percent relative standard deviation (\%RSD) of the total peak areas were $<3.36 \%$ which indicates that the developed method is precise.

\section{Accuracy}

The accuracy of the bioanalytical method is defined as the percent difference between the mean experimental value and true value. Accuracy was evaluated by conducting a recovery experiment in pre-analysed biological fluid (human and rat plasma). The assay was performed by following standard addition method at three different concentrations $(50 \%, 100 \%$ and $150 \%)$ of preanalysed trans-resveratrol samples in triplicates. The mean percent recovery of trans resveratrol from biological fluid were in the range of 94.44 to $97.44 \%$ with $<1$ $\%$ RSD. The results summarized in the Table 4. clearly indicate that the developed method displayed low variability and a strong agreement between experimental and true values.

\section{Trans-resveratrol stability}

Trans-resveratrol was stable for $6 \mathrm{~h}$ at $23^{\circ} \mathrm{C}-25^{\circ} \mathrm{C}$ and 7 days at freezing condition $\left(-20^{\circ} \mathrm{C}\right)$. Trans resveratrol was also stable for 3 freeze-thaw $(\mathrm{F} / \mathrm{T})$ cycles (Table 5). Comparison with previous published methods

Comparative analysis of methods described in the existing literature and the current study reveals the advantage of the developed method (Table 6). The developed method uses conventional solvents like water and ACN and has the flowrate of $1 \mathrm{~mL} \mathrm{~min}^{-1}$ with retention time of 6 min which suggests that it is economic, cheap and

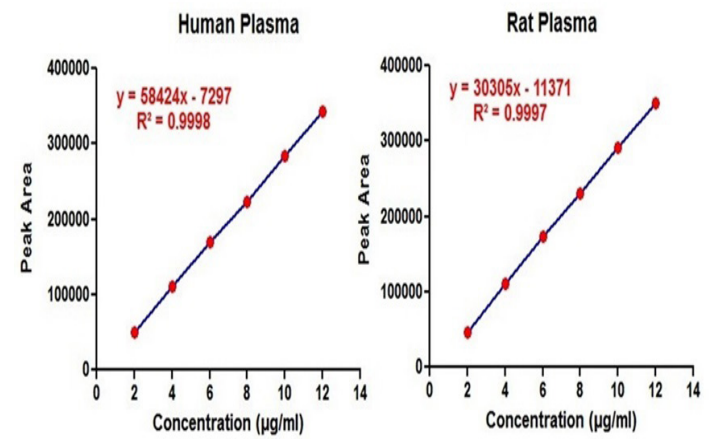

Figure 3: Linearity curve of trans resveratrol in human and rat plasma found to be linear over the range of $2-12 \mu \mathrm{g} \mathrm{mL}^{-1}$ with correlation coefficient; $r^{2}=0.999$.

\begin{tabular}{|c|c|c|}
\hline \multicolumn{2}{|c|}{ Table 2: Statistical evaluation of the calibration data. } \\
Parameters & $\begin{array}{c}\text { Human } \\
\text { plasma }\end{array}$ & $\begin{array}{c}\text { Rat } \\
\text { plasma }\end{array}$ \\
\hline Linearity range $\left(\mu \mathrm{g} \mathrm{mL}^{-1}\right)$ & $2-12$ & $2-12$ \\
\hline Slope & 58424 & 30305 \\
\hline Intercept & -7297 & -11371 \\
\hline Correlation coefficient & 0.999 & 0.999 \\
\hline Limit of detection $\left(\mu \mathrm{g} \mathrm{mL}^{-1}\right)$ & 0.0301 & 0.0327 \\
\hline Limit of quantification $\left(\mu \mathrm{g} \mathrm{mL}^{-1}\right)$ & 0.0909 & 0.0992 \\
\hline
\end{tabular}

\begin{tabular}{|c|c|c|c|c|c|}
\hline \multirow{2}{*}{ Samples } & \multirow{2}{*}{$\begin{array}{l}\text { Resveratrol } \\
\text { concentration } \\
\left(\mu \mathrm{g} \mathrm{mL}^{-1}\right)\end{array}$} & \multirow{2}{*}{$\begin{array}{c}\text { Intraday } \\
(n=6) \\
\text { Percent } \\
\text { RSD }\end{array}$} & \multicolumn{3}{|c|}{$\begin{array}{c}\text { Interday }(n=3) \\
\text { Percent RSD }\end{array}$} \\
\hline & & & Day 1 & Day 2 & $\begin{array}{c}\text { Day } \\
3\end{array}$ \\
\hline \multirow{3}{*}{$\begin{array}{l}\text { Human } \\
\text { plasma }\end{array}$} & 2 & 1.042 & 1.208 & 1.690 & 1.684 \\
\hline & 6 & 1.430 & 1.368 & 1.315 & 1.02 \\
\hline & 10 & 1.652 & 1.120 & 1.515 & 1.304 \\
\hline \multirow{3}{*}{$\begin{array}{c}\text { Rat } \\
\text { plasma }\end{array}$} & 2 & 3.20 & 1.48 & 3.36 & 1.68 \\
\hline & 6 & 1.37 & 1.42 & 1.99 & 2.37 \\
\hline & 10 & 2.06 & 2.12 & 1.19 & 1.26 \\
\hline
\end{tabular}

\begin{tabular}{|c|c|c|}
\hline \multicolumn{2}{|c|}{$\begin{array}{c}\text { Table 4: Determination of accuracy based on } \\
\text { percentage recovery }(\boldsymbol{n}=\mathbf{3}) \text {. }\end{array}$} \\
\hline Level of addition (\%) & Human plasma & Rat plasma \\
\hline 50 & 94.44 & 94.68 \\
\hline Percent RSD & 0.49 & 0.65 \\
\hline 100 & 95.09 & 95.25 \\
\hline Percent RSD & 0.27 & 0.36 \\
\hline 150 & 97.44 & 96.29 \\
\hline Percent RSD & 0.55 & 0.64 \\
\hline
\end{tabular}

RSD (Relative standard deviation); $n=$ number of replicate. 


\begin{tabular}{|c|c|c|c|c|c|}
\hline \multirow{2}{*}{$\begin{array}{l}\text { Spiked concentration } \\
\qquad\left(\mu \mathrm{g} / \mathrm{mL}^{-1}\right)\end{array}$} & \multirow{2}{*}{ Stability } & \multicolumn{2}{|c|}{ Human plasma } & \multicolumn{2}{|c|}{ Rat plasma } \\
\hline & & $\begin{array}{c}\text { Mean } \pm S^{a}\left(\mu \mathrm{g} / \mathrm{mL}^{-1}\right) \\
n=3\end{array}$ & Accuracy $(\%)^{b}$ & $\begin{array}{c}\text { Mean } \pm S^{\mathrm{a}}\left(\mu \mathrm{g} / \mathrm{mL}^{-1}\right) \\
n=3\end{array}$ & Accuracy $(\%)^{\mathrm{b}}$ \\
\hline \multirow{4}{*}{2} & $\mathrm{Oh}$ & $1.934 \pm 0.022$ & - & $1.958 \pm 0.015$ & - \\
\hline & $3 \mathrm{~F} / \mathrm{T}$ cycles & $1.891 \pm 0.027$ & 95.33 & $1.771 \pm 0.0132$ & 92.37 \\
\hline & $6 \mathrm{~h}$ & $1.920 \pm 0.012$ & 98.45 & $1.919 \pm 0.009$ & 95.87 \\
\hline & $\begin{array}{c}7 \text { days at } \\
-20^{\circ} \mathrm{C}\end{array}$ & $1.900 \pm 0.016$ & 92.39 & $1.941 \pm 0.028$ & 94.02 \\
\hline \multirow{4}{*}{6} & $\mathrm{Oh}$ & $5.973 \pm 0.006$ & - & $5.978 \pm 0.022$ & - \\
\hline & $3 \mathrm{~F} / \mathrm{T}$ cycles & $5.679 \pm 0.023$ & 95.07 & $5.837 \pm 0.027$ & 97.63 \\
\hline & $6 \mathrm{~h}$ & $5.753 \pm 0.056$ & 98.74 & $5.878 \pm 0.019$ & 98.74 \\
\hline & $\begin{array}{c}7 \text { days at } \\
-20^{\circ} \mathrm{C}\end{array}$ & $5.190 \pm 0.132$ & 93.05 & $5.812 \pm 0.028$ & 97.21 \\
\hline \multirow{4}{*}{10} & $\mathrm{Oh}$ & $9.876 \pm 0.039$ & - & $9.225 \pm 0.099$ & - \\
\hline & $3 \mathrm{~F} / \mathrm{T}$ cycles & $9.325 \pm 0.166$ & 94.42 & $8.927 \pm 0.202$ & 96.76 \\
\hline & $6 \mathrm{~h}$ & $9.753 \pm 0.056$ & 98.74 & $8.966 \pm 0.239$ & 97.19 \\
\hline & $\begin{array}{c}7 \text { days at } \\
-20^{\circ} \mathrm{C}\end{array}$ & $9.190 \pm 0.132$ & 93.05 & $8.872 \pm 0.109$ & 96.16 \\
\hline
\end{tabular}

Table 6: Comparison between HPLC methods reported in the literature.

\begin{tabular}{|c|c|c|c|c|c|c|}
\hline No. & Column & Mobile phase & $\begin{array}{l}\text { Separation } \\
\text { time (min) }\end{array}$ & Limitations & Applicability & References \\
\hline 1 & $\mathrm{C}_{18}$ & $\begin{array}{c}\text { Gradient elution } \\
\mathrm{NH}_{4} \mathrm{CH}_{3} \mathrm{CO}_{2}-5 \mathrm{mM} \\
\mathrm{CH}_{3} \mathrm{OH}, \mathrm{Propan}^{2}- \\
\text { ol- } 2 \%\end{array}$ & 18.6 & $\begin{array}{l}\text { Gradient elution; Longer run time; } \\
\text { Expensive equipment }\end{array}$ & $\begin{array}{c}\text { Human plasma and } \\
\text { urine }\end{array}$ & 9 \\
\hline 2 & $\mathrm{C}_{18}$ & $\begin{array}{c}3 \% \mathrm{CH}_{3} \mathrm{COOH}: \\
\mathrm{CH}_{3} \mathrm{CN}(20: 80, v / v)\end{array}$ & 11.7 & $\begin{array}{c}\text { Gradient elution; High flow rate; } \\
\text { Expensive equipment and hence } \\
\text { uneconomical }\end{array}$ & $\begin{array}{l}\text { Rat plasma and } \\
\text { tissue }\end{array}$ & 7 \\
\hline 3 & $\mathrm{C}_{18}$ & $\begin{array}{c}\mathrm{H}_{3} \mathrm{PO}_{4} 0.5 \% \mathrm{v} / \mathrm{v} \\
(\mathrm{pH} 6.8): \mathrm{CH}_{3} \mathrm{OH}: \\
(37: 63 \mathrm{v} / \mathrm{v})\end{array}$ & 3.94 & $\begin{array}{l}\text { Complete validation was not done; } \\
\text { system suitability parameters were } \\
\text { not mentioned }\end{array}$ & $\begin{array}{l}\text { Spiked human } \\
\text { plasma }\end{array}$ & 15 \\
\hline 9 & $\mathrm{C}_{18}$ & $\begin{array}{c}\mathrm{CH}_{3} \mathrm{OH}: \mathrm{CH}_{3} \mathrm{CN}: \\
0.1 \% \mathrm{H}_{3} \mathrm{PO}_{4} \\
(60: 10: 30 \mathrm{v} / \mathrm{v})\end{array}$ & 4.34 & $\begin{array}{l}\text { Method validation in plasma clearly } \\
\text { not given; stability studies not given }\end{array}$ & $\begin{array}{l}\text { PLGA nanoparticle } \\
\text { and human plasma }\end{array}$ & 16 \\
\hline 10 & $\begin{array}{l}\text { ODS } \\
\text { Hypersil }\end{array}$ & $\begin{array}{c}\mathrm{CH}_{3} \mathrm{CN}: 30 \mu \mathrm{M} \text { PBS } \\
(\mathrm{pH} 7.0) \\
(30: 70)\end{array}$ & 5.5 & No system suitability data given & Rat plasma & 5 \\
\hline 14 & $\mathrm{C}_{18}$ & $\begin{array}{c}\mathrm{CH}_{3} \mathrm{CN}: \mathrm{H}_{2} \mathrm{O} \\
(30: 70)\end{array}$ & 6.10 & $\begin{array}{c}\text { Economical, fast analysis, complete } \\
\text { validation and stability studies of } \\
\text { resveratrol in plasma }\end{array}$ & human and rat & $\begin{array}{l}\text { Present } \\
\text { method }\end{array}$ \\
\hline
\end{tabular}


fast when compared to other methods. Use of simple mobile phase without strong buffers/expensive HPLC grade solvents and a conventional $\mathrm{C}_{18}$ column makes the method versatile for the analysis of trans-resveratrol.

\section{Comparison with previous published methods}

Comparative analysis of methods described in the existing literature and the current study reveals the advantage of the developed method (Table 6). The developed method uses conventional solvents like water and ACN and has the flowrate of $1 \mathrm{~mL} \mathrm{~min}^{-1}$ with retention time of 6 min which suggests that it is economic, cheap and fast when compared to other methods. Use of simple mobile phase without strong buffers/expensive HPLC grade solvents and a conventional $\mathrm{C}_{18}$ column makes the method versatile for the analysis of trans-resveratrol.

\section{CONCLUSION}

A simple, sensitive and rapid RP-HPLC method was successfully developed according to the ICH guideline for the estimation of trans-resveratrol in human and rat plasma. The simple chromatographic conditions and pre-treatment procedure is easy and fast to perform. The acceptable limit of selectivity, precision, accuracy and appropriate retention time only 6 min make it suitable for preclinical and clinical studies.

\section{ACKNOWLEDGEMENT}

The authors gratefully acknowledge Sami Labs, Bangalore, India for gifting sample of pure trans-resveratrol. The authors are thankful to KLE Academy of Higher Education and Research, Belagavi for providing facility to carry out the study.

\section{CONFLICT OF INTEREST}

The authors declares no conflict of interest.

\section{ABBREVIATIONS}

ACN: Acetonitrile; ICH: International Council for Harmonisation; LC: Liquid chromatography; LOD: Limit of detection; LOQ: Limit of Quantitation; RP-HPLC:
Reverse Phase high performance liquid chromatography; RSD: Relative standard deviation; UV: Ultraviolet.

\section{REFERENCES}

1. Rajeshwari HR, Dhamecha D, Jagwani S. Formulation of thermoreversible gel of cranberry juice concentrate: Evaluation, biocompatibility studies and its antimicrobial activity against periodontal pathogens. Mater Sci Eng C. 2017;75:1506-14.

2. Lin HS, Ho PC. A rapid HPLC method for the quantification of 3,5 , 4'-trimethoxy-trans-stilbene (TMS) in rat plasma and its application in pharmacokinetic study. J Pharm Biomed Anal. 2009;49(2):387-92.

3. Kurangi B, Jalalpure S, Jagwani S. A validated stability-indicating HPLC method for simultaneous estimation of resveratrol and piperine in cubosome and human plasma. J Chromatogr B. 2019;1122-1123:39-48.

4. Zupančič Š, Lavrič Z, Kristl J. Stability and solubility of trans-resveratrol are strongly influenced by $\mathrm{pH}$ and temperature. Eur J Pharm Biopharm. 2015;93:196-204.

5. Das S, Ng KY. Quantification of trans-resveratrol in rat plasma by a simple and sensitive high performance liquid chromatography method and its application in pre-clinical study. J Liq Chromatogr Relat Technol. 2011;34(14):1399-414.

6. Katsagonis A, Atta PJ, Koupparis MA. HPLC Method with UV Detection for the Determination of trans-Resveratrol in Plasma. J Liq Chromatogr Relat Technol. 2015;28(9):1393-405.

7. Juan ME, Maijó M, Planas JM. Quantification of trans-resveratrol and its metabolites in rat plasma and tissues by HPLC. J Pharm Biomed Anal. 2010;51(2):391-8.

8. Frozza RL, Bernardi A, Paese K. Characterization of trans-resveratrol-loaded lipid-core nanocapsules and tissue distribution studies in rats. J Biomed Nanotechnol. 2010;6(6):694-703.

9. Boocock DJ, Patel KR, Faust GE. Quantitation of trans-resveratrol and detection of its metabolites in human plasma and urine by high performance liquid chromatography. J Chromatogr B. 2007;848(2):182-7.

10. U.S. Food and Drug Administration, Guidance for Industry: Bioanalytical Method Validation. Updated in 2013 and 2018. 2001. https://www.fda.gov/ downloads/Drugs/ GuidanceComplianceRegulatoryInformation/Guidances/ UCM070107.pdf

11. ICH guideline. M10: Validation of Analytical Procedure: Text and Methodology, International Conference on Harmonization. Available from: https://www.ich. org/fileadmin/Public_Web_Site/ICH_Products/Guidelines/Multidisciplinary/ M10/M10EWG_Step2_DraftGuideline_2019_0226.pdf

12. Mohamed FA, Khashaba PY, Shahin RY, El-Wekil MM. Determination of donepezil in spiked rabbit plasma by high-performance liquid chromatography with fluorescence detection. Royal Soc Open Sci. 2019;6(1):181476.

13. Garg NK, Singh B, Kushwah V. The ligand (s) anchored lipobridnanoconstruct mediated delivery of methotrexate: An effective approach in breast cancer therapeutics. Nanomedicine. 2016;12:2043-60.

14. Chen X, He H, Wang G. Stereospecific determination of cis-and transresveratrol in rat plasma by HPLC: Application to pharmacokinetic studies. Biomed Chrom. 2007;21(3): 257-65.

15. Singh G, Pai RS, Pandit V. Development and validation of a HPLC method for the determination of trans-resveratrol in spiked human plasma. J Adv Pharm Technol Res. 2012;3(2):130.

16. Kumar S, Lather V, Pandita D. Stability indicating simplified HPLC method for simultaneous analysis of resveratrol and quercetin in nanoparticles and human plasma. Food Chem. 2016;197(PtA):959-64.

\section{SUMMARY}

Developed RP-HPLC method was validated as per ICH (M10) guidelines for quantitative analysis of transresveratrol in human and rat plasma. Separation of trans-resveratrol was carried out by using Phenomenex Luna $\mathrm{C}_{18}$ column $(150 \times 4.6 \mathrm{~mm}, 5 \mu \mathrm{m})$ with optimized mobile phase comprised of acetonitrile/water in isocratic mode $(30: 70, \mathrm{v} / \mathrm{v})$ at the flowrate of $1.0 \mathrm{~mL} / \mathrm{min}$. Trans-resveratroldetected at UV wavelength of 306 $\mathrm{nm}$ with retention time of $6.1 \mathrm{~min}$. The developed bioanalytical method was rapid, simple and precise for the determination of trans resveratrol in plasma. 


\section{PICTORIAL ABSTRACT}

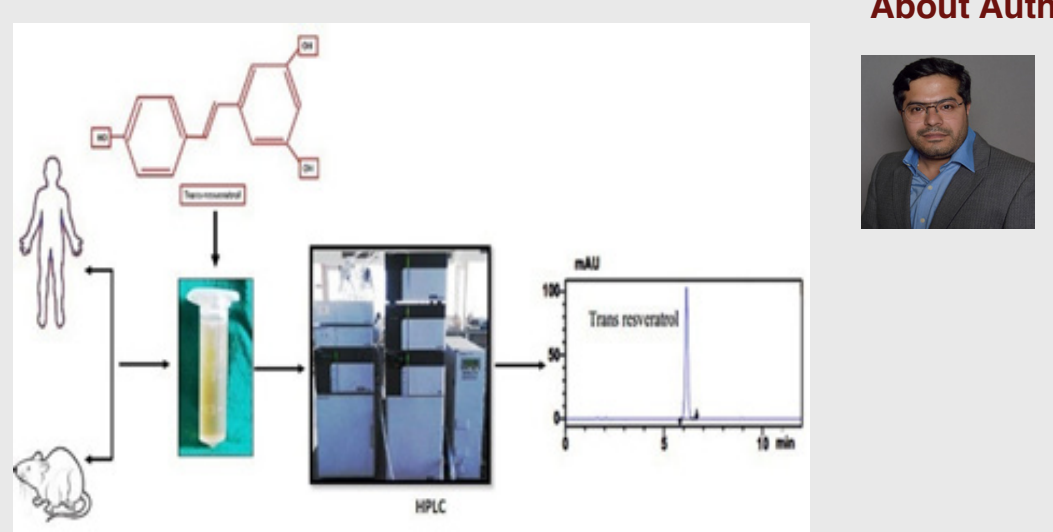

\section{About Authors}

Mr. Satveer Jagwani, is a Ph.D scholar at KLE College of Pharmacy, KLE Academy of Higher Education and Research, Belagavi. His current research interest are development of nanoparticles (lipid and metallic) and its biomedical application in the treatment of cancers, pharmacodynamic studies in animal models, cell culture based experiments.

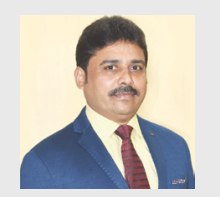

Dr. Sunil Jalalpure is presently working as a Professor, Department of Pharmacognosy, KLE College of Pharmacy, K.L.E Academy of Higher Education and Research, Belagavi. His areas of research interests include isolation/ characterization of active principles from medicinal plants and their pharmacological screening for various biological activities and training the research students in Pharmacognosy, Phytochemistry and Biotechnological aspects with modern tools and techniques. He is recently involved in nanoparticle drug delivery system of herbal actives and green nanotechnology.

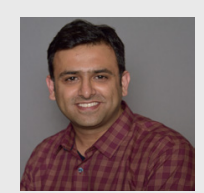

Dr. Dinesh Dhamecha has completed his Ph.D at KLE Academy of higher education and research. His Ph.D work involves design and characterization of metallic nanoparticles for anticancer activity. He is also involved in the area of drug delivery and nanomedicine.

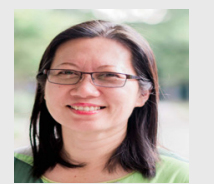

Dr. Gan Siew Hua has a B.Sc from Manchester University, a Masters in Clinical Pharmacy and a Ph.D in Pharmacology from Universiti Sains Malaysia (USM). Her research area is in the field of pharmacogenetics and toxicology.

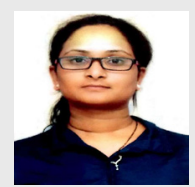

Dr. Kiran Jadhav has completed her Ph.D at KLE Academy of higher education and research. and M. Pharmacy in Quality Assurance from C. U. Shah College of Pharmacy, SNDT University in the year 2010. Her Ph.D work involves design and characterization of metallic nanoparticles for antimicrobial activity. She has two years of industrial experience in solid oral and tropical dosage forms.

Cite this article: Satveer Jagwani S, Jalalpure S, Dhamecha D, Hua GS, Jadhav K. Development and Validation of Reverse-Phase High-Performance Liquid Chromatographic Method for Determination of Resveratrol in Human and Rat Plasma for Preclinical and Clinical Studies. Indian J of Pharmaceutical Education and Research. 2020;54(1):187-93. 